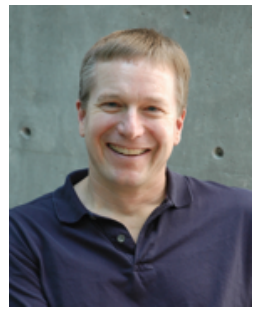

\title{
PUBLIC ON PAPER: THE FAILURE OF LAW TO PROTECT PUBLIC WATER USES IN THE WESTERN UNITED STATES
}

Reed D Benson

Professor, University of New Mexico School of Law, United States

\begin{abstract}
Water conflicts in the western United States increasingly arise from competition between traditional economic uses (especially irrigation, municipal supply and hydropower) and public uses (especially environmental protection and water-based recreation). Western United States water law, based on the prior appropriation doctrine, has always promoted maximizing 'beneficial use' of the resource and has effectively protected water allocations for traditional purposes. Public water uses also enjoy some legal protection, but it exists mostly on paper; in practice, neither statutory public interest provisions nor the non-statutory public trust doctrine has been widely effective. This paper identifies the relevant legal principles and briefly explains how they have failed to protect public water uses in the western United States.
\end{abstract}

\section{Public-private water conflicts in the American West}

Over the past decade, the most intense water controversies in the western United States have involved conflicts between ecosystem needs - specifically, the habitat requirements of species facing extinction - and established, traditional water uses such as irrigation, municipal supply, and hydropower generation. Examples include the Klamath Basin water crisis of 2001 (irrigation and hydropower versus salmon and sucker fishes), the Middle Rio Grande Basin dispute of the early 2000's (irrigation and municipal needs versus minnows and riparian birds), and the ongoing conflict on the Columbia River (primarily hydropower versus salmon). The fiercest current struggle over water in the West is in the California Central Valley, where irrigation and municipal demands are clashing with the habitat needs of salmon and smelt protected by the federal Endangered Species Act (ESA). ${ }^{1}$

These conflicts between traditional water uses and public uses, such as environmental protection and water-based recreation, are not new to the West. ${ }^{2}$ Until the late $20^{\text {th }}$ century, however, such conflicts typically arose from proposals for new dams that would destroy important stretches of free-flowing rivers; one such dispute, involving a proposed dam in Dinosaur National Monument, has been credited with launching the modern environmental movement. ${ }^{3}$ Supreme Court cases involving such conflicts go back more than half a century: consider the 1955 case where the State of Oregon opposed federal licensing of a proposed hydropower dam on the Deschutes River because the dam would harm salmon populations. ${ }^{4} \mathrm{~A}$ later case involved a challenge to the State of California's restrictions on a new federal dam (built largely to supply irrigation water), imposed partly to protect whitewater recreation on the Stanislaus River. ${ }^{5}$ As these cases might

\footnotetext{
16 USC §§ $1531-44$.

For purposes of this article, I define the West as the 11 contiguous states that lie entirely west of the $100^{\text {th }}$ meridian: Arizona, California, Colorado, Idaho, Montana, Nevada, New Mexico, Oregon, Utah, Washington, and Wyoming.

J McPhee, Encounters with the Archdruid (Farrar, Straus and Giroux, 1971) 164-5.

4 Federal Power Commission v Oregon, 349 US 435 (1955).

California v United States, 438 US 645 (1978).
} 
suggest, the western states have not always opposed protection of public water uses, especially where they were threatened by new, federally authorised projects.

Where public water uses have threatened established irrigation or municipal uses, however, the western states have typically resisted the allocation (or re-allocation) of water to the public use. Here again, two Supreme Court cases illustrate this phenomenon. In United States $v$ New Mexico, ${ }^{6}$ the state successfully opposed federal claims for in-stream flow rights for environmental and recreational purposes on national forest lands. And in Nevada v United States, ${ }^{7}$ the state prevailed in blocking efforts to reallocate water from a federal irrigation project to restore river and lake levels for fishery purposes, primarily to benefit an indigenous tribe.

Protection of existing, traditional uses is also at the heart of the recent disputes over ESA-listed species. The prominence of imperilled species in these conflicts is notable for at least two reasons. First, the decline of water-dependent fish and wildlife in the West indicates the extent to which aquatic and riparian ecosystems have been altered, often to the detriment of native species. ${ }^{8}$ Second, the need for ESA intervention to save native fish and wildlife species from extinction reflects the failure of state water laws to adequately protect aquatic and riparian habitats on which these species depend.

Disputes between established, traditional uses and public uses of water will only loom larger in the coming years. For the most part, the region's limited water supplies are already fully allocated and the legal system of the western states offers nearly complete protection for established uses. At the same time, the western states will continue to experience fairly rapid population growth, and the economy and values of today's West are increasingly geared towards a quality of life based on environmental and recreational amenities. Moreover, climate change appears increasingly likely to place increasing stress on water resources, especially in the driest parts of the West. It is therefore crucial that the law governing water resources provide an appropriate means for ensuring that water will be available for important public uses as well as the traditional purposes of irrigation, hydropower, and municipal supply.

\section{Traditional water uses under western United States water law}

Most of the American West is both arid and sparsely populated compared with the rest of the United States. Whereas most of the United States population lives where average annual precipitation is $1,000 \mathrm{~mm}$ (39 in) or more, most areas of the West average half that amount or less. With such limited natural water supplies, much of the West's agricultural land requires irrigation to grow reliable crops. Thus, although thermoelectric power plants are the largest water use category in the United States as a whole, ${ }^{9}$ that is not true in the western states.

\section{Traditional water uses in the American West}

The dominant use of water in the West is agricultural irrigation, accounting for the great majority of water withdrawals in every state - even heavily populated California. In fact, irrigation exceeds 60 per cent of freshwater withdrawals in all 11 states, ranging from 63 per cent in $\mathrm{Ne}$ -

438 US 696 (1978).

463 US 110 (1983).

M Moore, A Mulville and M Weinberg, 'Water Allocation in the American West: Endangered Fish Versus Irrigated Agriculture' (1996) 36(2) Natural Resources Journal 319, 348

9 J Kenny, N Barber, S Hutson, K Linsey, J Lovelace and M Maupin, 'Estimated Use of Water in the United States in 2005' (Research Report United States Geological Survey (US GS), 2009) 5. 
vada and Washington to nearly 96 per cent in Montana. Irrigation in the United States has been declining in recent years, with irrigated acres falling by two per cent and water withdrawals by eight per cent nationally from 2000 to $2005 .^{10}$

By contrast, municipal water use is a relatively small but growing source of water demand in the western states. The Interior West had the four fastest-growing states by percentage from 20002010, while California added nearly 3.4 million people, second only to Texas. ${ }^{11}$ Despite the rapid growth of cities such as Las Vegas, Phoenix, Salt Lake, and Denver, however, public water supply represents a modest share of water withdrawals in the western states; cities today make only about 28 per cent of freshwater withdrawals in Nevada, 19 per cent in Arizona, 13 per cent in Utah and 6 per cent in Colorado. Even in California, with roughly one-eighth of the entire United States population, cities account for only about 21 per cent of the state's total freshwater use. ${ }^{12}$

The other dominant, albeit non-consumptive, traditional water use in the western states is the generation of hydroelectric power. Among the major water resources regions in the United States, the Pacific Northwest leads the nation in hydropower production, while California (a region unto itself) is a distant second. These two basins account for about 60 per cent of United States hydropower production. The western Colorado and Missouri River Basins also generate significant hydropower, representing more than 10 per cent of United States production. ${ }^{13}$

\section{The prior appropriation doctrine and western water codes}

From the days of the 'Wild West,' water law in the western United States was overtly and intentionally pro-development. The early western courts and legislatures perceived that the commonlaw riparian rights doctrine, which favoured retention of water in its natural course for the benefit of those owning property along the stream, was not well suited to the harsh realities of the 'Great American Desert'. In most of the West, consistently-flowing streams were few and far between and lawmakers believed their water should be put to work wherever it was needed for mining, irrigation or any other productive activity that could attract people and money to the frontier. ${ }^{14}$ Thus, the western territories and states turned to the prior appropriation doctrine to allocate and manage their limited water resources.

Prior appropriation was (and largely remains) pro-development because of at least three fundamental principles, all of which were nearly polar opposites of the analogous elements of the riparian rights doctrine followed by other United States states. First, it not only allowed diversion of water from its natural course, it actually required diversion in order to establish a water right. Second, prior appropriation recognised a right to use water based on putting it to work; that is, a person gained a water right based on applying water to a 'beneficial use', not on land ownership. Third, it created a clear and rigid hierarchy among users to determine who had priority in times when demand for water exceeded the available supply, providing that the oldest

\footnotetext{
${ }^{10}$ Ibid 7, 23.

11 United States Census Bureau, Population Distribution and Change 2000-2010, (United States Department of Commerce, 2011) <http: / /www.census.gov/prod/cen2010/briefs/c2010br-01.pdf>.

${ }^{12}$ Kenny, above n 9, 7.

${ }^{13}$ W Solley, R Pierce and H Perlman, 'Estimated Use of Water in the United States in 1995' (Research Report, United States Geological Survey (US GS) Circular 1200) 55.

${ }^{14}$ As the United States Supreme Court wrote: 'the western states' choice of prior appropriation for allocating water 'became the determining factor in the long struggle to expunge from our vocabulary the legend "Great American Desert", which was spread in large letters across the face of the old maps of the far west'. California Oregon Power Co $v$ Beaver Portland Cement Co, 295 US 142, 158 (1935).
} 
established uses would trump more recent ones - often summarised as 'first in time, first in right'.

Originally developed by courts in disputes between water users, these principles were eventually incorporated into more-or-less comprehensive statutes adopted in all the western states. These water codes typically gave significant power to a state water agency to make decisions on proposed new water uses, changes to established uses and distribution of water supplies among existing users, as well as additional powers. But these codes invariably retained the core principles of prior appropriation, which effectively favoured both allocation of water to traditional uses and preservation of these uses once established. And, although the states have revised their codes somewhat over the years, ${ }^{15}$ they have continued to recognise permanent water rights based on beneficial use, and to give top priority to the oldest uses in times of shortage.

\section{Traditional water uses under state law}

The fundamental policy underlying the prior appropriation doctrine was to maximise beneficial use of water - that is, to ensure that water resources were fully and productively employed in the service of human activities. In order to promote investment in economically beneficial water development, the law provided for creation of secure rights to the use of water and sought to provide users with certainty regarding their actual water supplies.

Two major prerequisites for an appropriative water right ensured that traditional, extractive water uses were favoured in the allocation of the West's limited water supplies. Prior appropriation mandated that water be removed from its natural course as a threshold step in establishing a water right. This diversion requirement meant that no right could be obtained for in-place uses such as recreation, fishing, or even navigation. Moreover, prior appropriation did not necessarily recognise such uses as 'beneficial' for purposes of establishing a water right, even if they were economically valuable. These appropriation rules effectively foreclosed legal recognition of instream or in-lake uses that could have protected fish, wildlife, or recreation, regardless of their antiquity or their importance.

It is true that over the past few decades, state water laws have evolved away from these rigid rules. The law increasingly recognises fish, wildlife, and recreation as beneficial uses of water, and statutes have created limited exceptions to the diversion requirement for purposes of recognising rights to water left flowing in its natural course. This evolution in the law, however, is of limited practical importance because of the steadfast appropriation principle of 'first in time, first in right'. That principle strongly encouraged users to acquire water rights at the earliest possible date, resulting in many streams that were fully appropriated well before the end of the $19^{\text {th }}$ century. It has also limited the success of in-stream flow programs by making all pre-existing water rights superior to newly created flow protections. ${ }^{16}$ In short, the seniority element of prior appropriation, along with the century of traditional water development preceding the recognition of in-stream flow rights, combine to undermine the effect of the recent legal reforms.

This bias in allocation would be a lesser problem for public water uses if there was an effective means of revisiting or scrutinising established water uses in response to competing demands.

\footnotetext{
${ }^{15} \mathrm{~N}$ Johnson and C DuMars, 'A Survey of the Evolution of Western Water Law in Response to Changing Economic and Public Interest Demands (1989) 29(2) Natural Resources Journal 347, 356-87.

${ }^{16}$ D Gillilan and T Brown, Instream Flow Protection: Seeking a Balance in Western Water Use (Island Press, 1997) 31-2, 144-5.
} 
Both legally and practically, however, the water use status quo enjoys enormous protection in the West. As for the law, established water users claim property rights to the use of water, and these rights last forever so long as water is actively used. In other words, water rights are perpetual, unlike many other government approvals to use natural resources (including hydropower dam licenses ${ }^{17}$ ). Water rights may be changed to a new place or new type of use (for example, irrigation to urban), but even here existing uses are protected, as such transfers are not allowed to 'injure' other water rights by reducing the amount of water available to them. And water law makes no real effort to revisit or improve established practices, unlike other laws governing activities that affect the environment (such as water quality regulation). In practical terms, the states do not actively scrutinise existing water rights for purposes of determining whether water use practices could be changed to improve efficiency or reduce impacts on other users or the environment. Even the continuing requirement of 'beneficial use without waste', whereby states would have fairly clear authority to examine existing uses and curtail those deemed to be excessive, has gone largely unenforced. ${ }^{18}$ The strong security enjoyed by established traditional uses stands in sharp contrast to the paper-thin protection for public water uses, as the next section explains.

\section{Legal protection for public water uses}

In an earlier day, public versus private water disputes in the West often involved new water projects that threatened free-flowing rivers, such as the dam proposals mentioned above. Now that western rivers are already heavily developed, however, protecting public water uses typically presents a conflict with established irrigation, municipal or hydropower uses. This section identifies significant public water uses in the West then examines legal principles that could benefit such uses by limiting the exercise of existing water rights.

\section{Public water uses in today's West}

The most widely recognised public water use in the western states is protection of fish and wildlife habitat. Most states now have statutory programs that allow for legal recognition of water left to flow in its natural course, primarily to protect fish habitat. Although such in-stream flow programs often provide limited protection in practice, ${ }^{19}$ they do reflect the value that many westerners place on fish and fishing. Flow protections under state law tend to focus on sport fishes such as trout, rather than on rare species protected by the ESA. While protection of flows for endangered species habitat is often challenged because of the potential economic harm it may cause to water users, ${ }^{20}$ protection of flows for sport fish supports a major industry in a region where outdoor activities and associated tourism are big business.

\footnotetext{
${ }^{17}$ The Federal Power Act limits hydropower dam licenses to a maximum of 50 years, 16 USC $\S 799$, and when a license expires the Federal Power Commission has great discretion to impose conditions for purposes of protecting various national or public interests, even if such conditions make the project uneconomical to operate in the future. Tacoma $v$ Federal Energy Regulatory Commission, 460 F 3d 53 (DC Cir, 2006).

$18 \mathrm{~J}$ Neuman, Beneficial Use, Waste, and Forfeiture: The Inefficient Search for Efficiency in Western Water Use' (1998) 28(4) Environmental Law, 919, 995-6.

${ }^{19}$ R Benson, “"Adequate Progress,” or Rivers Left Behind? Developments in Colorado and Wyoming Instream Flow Laws Since 2000’ (2006) 36(4) Enviromental Law 1283, 1286-92.

${ }^{20} \mathrm{See}$, eg, The Consolidated Delta Smelt Cases, $717 \mathrm{~F}$ Supp 2d 1021, 1069-70 (ED Cal, 2010) (noting potential economic and other harms to irrigators and agricultural communities resulting from water use restrictions imposed to protect endangered delta smelt).
} 
Two other public water uses - water quality protection, and water-based recreation - are also increasingly important. Many of the West's stubborn water quality problems are associated with water management and use under state water allocation laws, ${ }^{21}$ and both the federal Environmental Protection Agency and the states could take steps to mitigate such problems by promoting a healthier flow regime. ${ }^{22}$ As for recreational water uses such as rafting and kayaking, they offer both quality of life and significant economic benefits, as indicated by the popularity among Colorado river towns of special recreational water rights to provide adequate flows for engineered kayak courses. ${ }^{23}$

In general, commercial navigation has not been an important public water use in the interior western states, unlike the earlier United States states along the East and Gulf Coasts, the Great Lakes, and the Mississippi and Ohio Rivers. Western rivers tend to be relatively small, and to experience huge seasonal and annual variations in flow, so they have not played a major role in the transportation of goods and people in most parts of the region.

\section{Public provisions in western water law}

The water laws of the western states include a variety of 'public' elements, including general constitutional or statutory provisions asserting public ownership of water resources, public interest standards that apply to particular kinds of decisions and the judicially created public trust doctrine.

\section{State constitutional/statutory declarations of water ownership}

Several western state constitutions declare in some way that the waters of the state are a public (or state) resource. For example, the Colorado Constitution states, "The water of every natural stream, not heretofore appropriated, within the state of Colorado, is hereby declared to be the property of the public, and the same is dedicated to the people of the state, subject to appropriation as hereinafter provided. ${ }^{24}$ In the New Mexico Constitution, 'The unappropriated water of every natural stream, perennial or torrential, within the state of New Mexico, is hereby declared to belong to the public and to be subject to appropriation for beneficial use, in accordance with the laws of the state' ${ }^{25}$ (As these provisions indicate, several of the western states also have prior appropriation written into their state constitutions.)

Other western states enacted statutes declaring water to be a public resource. For example, the first section of the Utah water code provides, "All waters in this state, whether above or under the ground, are hereby declared to be the property of the public, subject to all existing rights to the use thereof. ${ }^{26}$ Similarly, Oregon's water code begins by stating, 'All water within the state from all sources of water supply belongs to the public. ${ }^{27}$

\footnotetext{
${ }^{21}$ D Getches, L MacDonnell and T Rice, Controlling Water Use; The Unfinished Business of Water Quality Protection (Natural Resources Law Centre, 1991) 6-7.

22 R Benson, 'Pollution without solution: Flow Impairment problems Under the Clean Water Act Section 303'(2005) 24(2) Stanford Environmental Law Journal 199, 256-65.

${ }^{23}$ G Porzak, S Bushong, P Holleman and L MacDonnell, 'Recreation water rights; "The inside story"' (2007) 10(1) University of Denver Water Law Review 209, 210-13; R Benson, 'Rivers to Live By: Can Western Water Law Help Communities Embrace Their Streams?' (2007) 27(1) Journal of Land, Resources, and Environmental Law 1, 16-8, 22-4.

${ }^{24}$ Colorado Constitution art XVI § 5.

${ }^{25}$ New Mexico Constitution art XVI § 2.

${ }^{26}$ Utah Code Ann $\$ 73-1-1$.

${ }^{27}$ Or Rev Stat § 537.110.
} 


\section{Statutory public interest provisions}

When the western states (beginning with Wyoming in 1890) adopted comprehensive water codes governing the allocation and management of their waters, they generally gave substantial authority to state agencies - typically a 'State Engineer' and his staff - to make decisions on proposals for new water uses, or for changes to existing uses. Most codes provided that such decisions on 'permits' for new uses and 'transfers' of existing rights were to be made initially by the agency, subject to judicial review. The codes invariably prohibited the agency from approving proposals that would harm existing users, but many also required the agency to consider whether approving the application would somehow harm the public interest in water.

Public interest provisions today are most common in the context of decisions on whether to authorise an entirely new water use. The Wyoming Constitution contains perhaps the original public interest test: 'No appropriation shall be denied except when such denial is demanded by the public interest. ${ }^{28}$ More commonly, states have established public interest tests for permitting by statute, such as Utah's requirement that the proposed water use 'would not prove detrimental to the public welfare. ${ }^{29}$

Some states have also imposed a public interest test on transfers - that is, proposals to change the purpose for which the water is used, the location of use, or the place where water is diverted or pumped. For example, a New Mexico statute allows a water right to be changed to a new type or place of use if the change meets certain standards, including that it be 'not detrimental to the public welfare of the state. ${ }^{30}$

\section{Public trust doctrine}

A third potential source of legal protection for water resources in the western United States is the public trust doctrine (PTD). The PTD is unlike the others in that it is judicially rather than legislatively created, although it arguably has constitutional underpinnings.

In the seminal PTD case in the United States, Illinois Central Railroad Co. v Illinois (Illinois Central) ${ }^{31}$ the United States Supreme Court upheld the State of Illinois' revocation of its 1869 grant to the railroad of fee title to a substantial part of the submerged lands underlying the City of Chicago's busy harbour on Lake Michigan. The Court noted that the states hold title to the submerged lands beneath their navigable waters, but not the kind of title that allowed the states to dispose freely of these lands: 'It is a title held in trust for the people of the State that they may enjoy the navigation of the waters, carry on commerce over them, and have liberty of fishing therein freed from the obstruction or interference of private parties.' The states may not abdicate their general authority over such lands, as that would not be 'consistent with the exercise of that trust which requires the government of the State to preserve such waters for the use of the public' - a trust that 'can only be discharged by the management and control of property in which the public has an interest .... ${ }^{32}$ The Court declared that states are limited in conveying assets subject to the trust:

[S] uch property is held by the State, by virtue of its sovereignty, in trust for the public. The ownership of the navigable waters of the harbor and of the lands under them is a subject of

\footnotetext{
${ }^{28}$ Wyoming Constitution art $8 \S 3$.

${ }^{29}$ Utah Code Ann §73-3-8(1)(a).

${ }^{30}$ NM Stat § $72-5-23$.

146 US 387 (1892).

32 Ibid 452-53.
} 
public concern to the whole people of the State. The trust with which they are held, therefore, is governmental and cannot be alienated, except in those instances mentioned of parcels used in the improvement of the interest thus held, or when parcels can be disposed of without detriment to the public interest in the lands and waters remaining. ${ }^{33}$

The Court stated that this principle 'follows necessarily from the public character of the property', and quoted an influential state court decision stating, 'The sovereign power, itself, therefore, cannot consistently with the principles of the law of nature and the constitution of a well-ordered society, make a direct and absolute grant of the waters of the State, divesting all the citizens of their common right. ${ }^{34}$

The legal foundation of the PTD is a subject of ongoing disagreement, in part because the Illinois Central opinion is not clear on that point. Various legal bases have been advanced for the PTD, including some based on the United States Constitution, although the Supreme Court has repeatedly stated that the PTD is state law. ${ }^{35}$ In the western states, Illinois Central has been viewed as establishing the minimum requirements for the scope of the PTD; some states have gone no further, while others have extended the PTD as a matter of state law. ${ }^{36}$ Given that the primary United States Supreme Court case involved access to the shore and bed of a navigable lake, it is not surprising that courts throughout the country have applied the PTD primarily in 'facilitating public access to and use of tidelands and beaches'. ${ }^{37}$

In most of the West, however, neither the PTD nor state constitutional or statutory provisions have done much to ensure that public uses have the water they need, as western states have opted instead to protect established uses under appropriative water rights.

\section{Failure of legal protections in practice}

\section{State ownership has meant little, except for rights of recreational access}

Constitutional or statutory provisions declaring some type of state or public ownership of waters are common in the western states. In several of the states, courts have interpreted these provisions as ensuring a public right of recreational access to streams or lakes capable of recreational use. Most recently, the Utah Supreme Court applied a statute making all waters within the state 'property of the public' to uphold a right of recreational access, not only to use the surface of the water, but also to touch underlying streambeds if the touching is both reasonable and incidental to lawful recreational uses. ${ }^{38}$ The court stated that public ownership creates a public easement to use Utah's waters, regardless of who owns the underlying beds, in furtherance of a state policy in favour of public recreational use of waters. The easement includes the 'right to float leisure craft, hunt, fish, and participate in any lawful activity when utilising that water.'39 Most western state courts which have considered this question have interpreted their state own-

\footnotetext{
33 Ibid 455-6.

34 Ibid 456, quoting Arnold $v$ Mundy, 6 NJ Law 1.

${ }^{35}$ D Grant, 'Underpinnings of the Public Trust Doctrine: Lessons from Illinois Central Railroad' (2001) 33(3) Arizona State Law Journal 849, 852-5.

${ }^{36}$ R Craig, 'A Comparative Guide to the Western States' Public Trust Doctrines: Public Values, Rrivate Rights, and the Evolution Toward an Eecological Public Trust' (2010) 37(1) Ecology Law Quarterly 53, 71-80.

37 J Ruhl and S Salzman, 'Ecosystem Services and the Public Trust Doctrine: Working Change from Within' (2006) 15(1) Southeastern Environmental Law Journal 223, 228.

${ }^{38}$ Conatser $v$ Johnson, 194 P $3 d 897$ (Utah, 2008).

39 Ibid 899-900, quoting JJNP Co v State, 655 P 2d 1133, 1137 (Utah, 1982).
} 
ership provisions as providing a generally similar right of public recreational access to waters suitable for recreational use ${ }^{40}$ even if the beds are privately owned.

Beyond the right of public access, however, these constitutional and statutory provisions have meant relatively little in terms of public rights (or state responsibilities) regarding water resources. Such provisions have not operated to limit new water allocations that could impair public uses, or to curtail established allocations that have impaired such uses. Nor have they been interpreted to impose a duty on states to ensure that water is available for public uses as against established water rights. Thus, although public ownership of waters has prevented owners of land from excluding recreational users from the water surface, it has not kept owners of water rights from dewatering streams and lakes to the detriment of recreation and other public uses. The narrow effect of these ownership declarations comports with the view of the great scholar Frank Trelease, who insisted that they added little or nothing to state legal power over water. $^{41}$

Public ownership provisions have meant much to the public by guaranteeing the 'right to float' over otherwise-private lands - a right that has long been as controversial as it is important. But the failure of such provisions to influence the management or allocation of water limits the practical value of the right to float. Worse, it affords no protection to environmental values (including fish and wildlife habitat) that provide a wide range of public benefits, including recreation.

\section{Public interest provisions have had little effect on water allocation}

Public interest standards, which apply to permit applications in most western states and to transfer proposals in some states, provide the most clearly applicable protection for public water uses. The actual effect of these provisions is somewhat difficult to assess, in that states do not systematically publish the results of their public interest reviews on individual permit or transfer requests. For a variety of reasons, however, I believe these public interest statutes have had little effect in protecting environmental and recreational water uses, especially from the effects of established water rights.

Two of the problems appear on the face of the statutes themselves. First, they apply only to certain kinds of applications, primarily new permits. While the states still issue some new permits (primarily to pump groundwater), there are few places in the West that still have any surface water left to appropriate; in these places no new permits will be issued because the reliably available water is already taken, not because of the public interest. Where new permits are unobtainable, water for new or expanded uses must come from transfers of existing rights; thus, public interest standards for transfers may be important, although they apply in fewer states. But given that most water transfers in the West involve movement of water from irrigation to urban, industrial or environmental uses, public interest standards for transfers may operate to protect traditional agricultural uses as much or more than they protect public uses.

This last point raises the second problem with statutory public interest provisions. Most of them provide little if any guidance on what the public interest requires or how it should be applied to

\footnotetext{
${ }^{40}$ See State Game Commission v Red River Valley Co., 182 P $2 d 421$ (New Mexico, 1945); Day v Armstrong, 362 P $2 d 137$ (Wyoming, 1961); Montana Coalition for Stream Access v Curran, 682 P 2d 163 (Montana, 1984). But see People v Emmert, 597 P 2d 1025 (Colorado, 1979) (interpreting state constitutional provision not to provide a public right of recreational access, but rather to ensure that waters of the state remained available for appropriation).

${ }^{41}$ F Trelease, 'Government Ownership and Trusteeship of Water' (1957) 45 California Law Review 638, 644-5.
} 
a particular application. Many of the statutes do not define the public interest, leaving interpretation to the agencies and courts. Even where statutes or judicial decisions flesh out the meaning of the term, the result is often simply a laundry list of factors or values to be considered, with no indication of which ones get priority in the (seemingly inevitable) event of a conflict. ${ }^{42}$ These provisions say nothing about how to balance economic benefits against environmental harms, for example, or whether to approve a transfer that would mean more water for a growing city but less for a traditional agricultural community. One thing is clear: while these provisions confer great discretion to make decisions that would protect public water uses, their language does not require the states to give priority to such uses.

Given both the limited applicability and the vagueness of most public interest statutes, it is no surprise that they have done little to protect environmental and recreational water uses in the West. In some states, at least, water agencies have been reluctant to apply the public interest standard at all. ${ }^{43}$ Although the Nevada State Engineer has indeed applied the public interest test in a number of decisions, he has essentially interpreted it simply to reinforce other provisions of Nevada water law, for example requirements regarding beneficial use, water availability, and protection for existing users. ${ }^{44}$ There is no indication that public interest provisions have caused the western states to deny permits or transfers they would have otherwise approved; to the contrary, the absence of any reported judicial decision reviewing a denial based solely or primarily on this ground strongly indicates that the states are not using the public interest in this way.

\section{The public trust doctrine has had little effect on water use outside California}

The PTD governs the allocation and management of water resources in California, where a famous decision of the state's highest court applied the doctrine to protect the water level of navigable Mono Lake. ${ }^{45}$ The water utility serving faraway Los Angeles had obtained a state permit in 1940, allowing it to divert nearly all the water from certain creeks feeding the lake. After years of taking only a fraction of the water allowed under the permit, the utility increased its diversions and began diverting nearly all the water from four of Mono Lake's five tributary creeks, resulting in increasingly serious environmental impacts. State water law, based on prior appropriation, offered little hope that the lake could be saved from the exercise of the utility's valid permit. But the court held that the PTD protected the waters of Mono Lake from being depleted to the detriment of human and ecosystem values. The California Supreme Court in 1971 had expanded the interests protected by the PTD to include environmental and recreational values, ${ }^{46}$ and held in the Mono Lake case that the PTD applies to water diversions, not simply to submerged lands. The court recognised that California had come to rely heavily on water withdrawals for a range of human uses, and confirmed that it was not invalidating prior appropriation or diversionary water rights. It declared, however, that the PTD must apply in this context to ensure that California water law was appropriately balanced, ensuring adequate consideration of

\footnotetext{
${ }^{42}$ See Shokal v Dunn, 707 P 2d 441, 448-50 (Idaho, 1985) (identifying factors relevant to the determination of 'local public interest' under Idaho law, but stating that the agency has discretion in applying those factors).

${ }^{43}$ See William F West Ranch v Tyrrell, 206 P 3d 722 (Wyo, 2009) (plaintiffs challenged Wyoming State Engineer's failure to consider the public interest in issuing water use permits for natural gas extraction, but court held that they had failed to present a justiciable controversy).

${ }^{44}$ A Weeks, 'Defining the Public Interest: Administrative Narrowing and Broadening of the Public Interest in Response to the Statutory Silence of Water Codes' (2010) 50(1) Natural Resources Journal 255, 260-72.

${ }^{45}$ National Audubon Society v Superior Court of Alpine County, 33 Cal 3d 419, 658 P 2d 709 (1983).

${ }^{46}$ Marks v Whitney, 6 Cal 3d 261, 491 P 2d 374 (1971).
} 
both the economic interests advanced by prior appropriation and the public values protected by the PTD.

Under the Mono Lake decision, the PTD imposes not only limits on the state's power to convey trust resources, but also affirmative duties on the state in managing those resources. Remarkably, those duties apply even to waters that have been validly appropriated under state law and actively used under existing water rights - as was true of the waters diverted by Los Angeles from the Mono Lake tributaries. The court defined the state's ongoing responsibility over such waters as follows:

Once the state has approved an appropriation, the public trust imposes a duty of continuing supervision over the taking and use of the appropriated water. In exercising its sovereign power to allocate water resources in the public interest, the state is not confined by past allocation decisions which may be incorrect in light of current knowledge or inconsistent with current needs.

The state accordingly has the power to reconsider allocation decisions even though those decisions were made after due consideration of their effect on the public trust. The case for reconsidering a particular decision, however, is even stronger when that decision failed to weigh and consider public trust uses. ${ }^{47}$

In other words, the state's power to consider the public interest in water allocation does not end with approval or recognition of a water right. To the contrary, the state not only has authority to revisit established water allocations, but also a 'duty of ongoing supervision' to assess existing uses in relation to today's knowledge and needs regarding water resources. That duty has continuing practical relevance in the never-ending disputes between private and public water uses in California. ${ }^{48}$

On paper at least, the PTD offers the most meaningful protection for public uses in the West, in that it is the only law that clearly authorises reduction of established water rights and uses. By giving the states continuing powers and duties that apply even to existing allocations, the PTD has long been a source of inspiration and hope for some people, but an object of fear and loathing for others. And because the latter group includes established water users and their political allies, both of whom have been strongly influential in western state water law and policy, the PTD has not been eagerly embraced in the water use context. Among the eleven western states, ${ }^{49}$ only California has applied it to limit the exercise of water rights.

The Idaho experience with the PTD as applied to water is instructive. In the 1983 Kootenai case ${ }^{50}$ involving submerged lands and a proposed sailboat dock, the Idaho Supreme Court adopted California's statement of the PTD, and even noted that the Mono Lake case had ruled that the PTD 'takes precedent [sic] even over vested water rights ... ${ }^{51}$ In a later case involving the state's water use permitting statute, ${ }^{52}$ the Idaho court included an extended footnote discussing the Kootenai decision; this note suggested even more strongly that the PTD applied to water allocation in Idaho, stating that the state 'holds all waters in trust for the benefit of the public', and that values protected by the PTD include 'property values, "navigation, fish and wildlife habitat,

\footnotetext{
${ }^{47}$ National Audubon Society, 33 Cal 3d 419, 658 P 2d 709 (1983).

${ }^{48}$ P Kibel, 'The Public Trust Navigates California's Bay Delta' (2011) 51(1) Natural Resources Journal 35.

49 The PTD has also become important to water law in Hawai'i, but there is a strong constitutional foundation for apply-

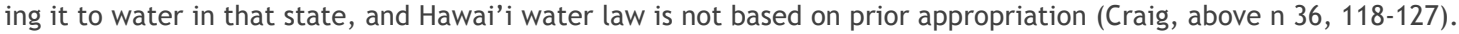

${ }^{50}$ Kootenai Environmental Alliance v Panhandle Yacht Club, 671 P 2d 1085, 1094 (Idaho, 1983).

51 Ibid, citing Mono Lake, 658 P 2d, 723.

52 Shokal v Dunn, 707 P 2d 441 (Idaho, 1985).
} 
aquatic life, recreation, aesthetic beauty and water quality"'. ${ }^{53}$ Thus, Idaho seemed poised to apply the PTD to established water rights, as California had in the Mono Lake decision. But when environmental groups sought to require consideration of the PTD in the adjudication of all existing water rights in the Snake River Basin, the Idaho Supreme Court retreated, initially denying that it had ever applied the PTD to water, and later ruling that the PTD could not be considered in the adjudication. ${ }^{54}$ And in response to the Idaho court's statement that Idaho water rights nonetheless 'are held subject to the public trust', ${ }^{55}$ the Idaho Legislature quickly passed a statute purporting to prohibit application of the PTD to water rights. ${ }^{56}$

Arizona might be seen as an exception to the western states' reluctance to apply the PTD to water rights, given that its supreme court rejected a legislative attempt to preclude application of the PTD in water right adjudications, holding the statute unconstitutional. ${ }^{57}$ Since then, however, the PTD has not been a litigated issue in Arizona adjudications, and it appears to have no practical relevance to water rights or water management in the state. Thus, while the court protected the PTD from legislative tampering, the PTD has not in turn protected Arizona's waters from depletion caused by traditional uses. ${ }^{58}$

In short, the PTD - like state constitutional and statutory provisions - has had limited practical impact in ensuring adequate water supplies for public uses. This ongoing failure poses some risks for private as well as public water users, and for the states themselves, as identified in the conclusion.

\section{Conclusion}

Many scholars have commented that western water law has evolved to address new demands and needs. ${ }^{59}$ The question has been whether the states are going fast enough or far enough in reforming their laws. Getches wrote that the western states in the 1980s had recognised the need for reforms, but did little to implement them in the following decade, and that the states had largely responded to federal pressures in making the modest revisions they did. ${ }^{60}$ He suggested that if the states continued to resist modernizing their water laws, western water policy would evolve in spite of the states' efforts, not because of them. And indeed, the next decade saw the federal ESA play an increasingly important role in driving water policy and management in the West, to the chagrin of both the states and traditional water users whose supplies were disrupted or threatened.

Getches earlier wrote that water law provided too little protection for public values, and insisted that 'greater public benefits can be produced without upsetting attributes of [the] present

\footnotetext{
53 Ibid, quoting Kootenai Environmental Alliance, 671 P 2d 1085, 1095.

${ }^{54}$ Idaho Conservation League v State of Idaho, 911 P 2d 748 (Idaho, 1995).

${ }^{55}$ Ibid 750, citing Kootenai Environmental Alliance, 671 P 2d 1085, 1094.

${ }^{56}$ M Blumm, H Dunning and S Reed, 'Renouncing the Public Trust Doctrine: An Assessment of the Validity of Idaho House Bill 794' (1997) 24(2) Ecology Law Quarterly 461, 478-96 (presented a strong argument that the Idaho statute was invalid, but it has not been challenged in the 15 years since its enactment).

${ }^{57}$ San Carlos Apache Tribe v Superior Court ex rel County of Maricopa, 972 P 2d 179, 199 (Ariz, 1999) (stating that the PTD is 'a constitutional limitation on legislative power to give away resources held by the state in trust for its people', which the legislature could not destroy by statute).

${ }^{58}$ By contrast, the PTD has effectively prevented the beds and banks of Arizona's navigable waters from being transferred into private ownership free of the trust (Craig, above $n$ 36, 102-104).

59 Johnson and DuMars, above n 15; D Tarlock, 'The Public Trust Doctrine: A Conservative Reconstruction and Defense' (2006) 41(3) Natural Resources Journal 769, 770-1.

60 D Getches, 'The Metamorphosis of Western Water Policy; Have Federal Laws and Local Decision Eclipsed the States' Role?' (2001) 20(1) Stanford Environmental Law Journal 3, 69-72.
} 
system that have served private water allocation needs. Inaction is the greatest enemy of the system because it will license the courts and others to impose remedies that may be incompatible with private rights' ${ }^{61}$ Many would see the PTD as just such a remedy, threatening curtailment of existing water rights. ${ }^{62}$ Inaction has been the prevailing practice, however, as states have continued to favour established uses over protection of public values. But the pressures for change in western water law keep building as the West adds millions of new people, sees environmental water needs go unmet and faces the reality that climate change will only make it harder for the region to balance water supply and demand. If the western states drag their feet in response to such pressures, they may face a growing risk of PTD litigation over their water allocation and management decisions, and with it the possibility that courts will take it upon themselves to protect public water uses.

Keywords: water uses, public water uses, prior appropriation doctrine, public trust doctrine, environmental protection

\footnotetext{
${ }^{61}$ D Getches, 'Pressures for Change in Western Water Policy' in D Getches (ed), Water and the American West: Essays in Honor of Raphael J. Moses (natural Resources Law Centre, 1997) 143, 161. Getches was referring specifically to Colorado, but his point was (and still is) more or less valid for all western states.

${ }^{62}$ B Thompson, 'The public trust doctrine: A Conservative 'Reconstruction and Defense' (2006) 15(1) Southeastern Environmental law Journal 47, 54-8; R Walston, 'The public trust doctrine in the Water Rights Context: The Wrong Environmental Remedy’ (1982) 22(1) Santa Clara Law Review 63.
} 